NBER WORKING PAPER SERIES

\title{
DEFLATION, SILENT RUNS, AND BANK HOLIDAYS, IN THE GREAT CONTRACTION
}

\author{
Hugh Rockoff \\ Working Paper 9522 \\ http://www.nber.org/papers/w9522 \\ NATIONAL BUREAU OF ECONOMIC RESEARCH \\ 1050 Massachusetts Avenue \\ Cambridge, MA 02138 \\ February 2003
}

The views expressed herein are those of the author and not necessarily those of the National Bureau of Economic Research.

(C)2003 by Hugh Rockoff. All rights reserved. Short sections of text not to exceed two paragraphs, may be quoted without explicit permission provided that full credit including Cnotice, is given to the source. 
Deflation, Silent Runs, and Bank Holidays, in the Great Contraction

Hugh Rockoff

NBER Working Paper No. 9522

February 2003

JEL No. N12

\begin{abstract}
This paper argues that the banking crises in the United States in the early 1930s were similar to the "twin crises" -- banking and balance of payments crises -- which have occurred in developing countries in recent years. The downturn that began in 1929 undermined banks that had made risky loans in the twenties. The deflation that followed further weakened the banks, especially in rural areas where the deflation in prices and incomes was the greatest. Depositors in those areas began transferring their deposits to banks they regarded as safer, or purchasing bonds. These "silent runs," essentially a capital flight, have been neglected in many accounts of the banking crises. But evidence from the Gold Settlement Fund (which recorded interregional gold movements) and from regional deposit movements suggests that silent runs were important, especially in the crucial year 1930. When the crisis worsened, state and local authorities began declaring "bank holidays," which limited the right of depositors to make withdrawals, a movement that culminated in the declaration of a national bank holiday by President Roosevelt.
\end{abstract}

\author{
Hugh Rockoff \\ Department of Economics \\ Rutgers University \\ New Brunswick, NJ 08901 \\ and NBER \\ rockoff@econ.rutgers.edu
}




\section{Deflation, Silent Runs, and Bank Holidays, in the Great Contraction ${ }^{1}$}

\section{Separate Regions with Separate Banking Systems}

The Great Contraction of 1929 to 1939, as Friedman and Schwartz (1963)

designated it, must surely be the most carefully studied episode in American monetary

history. Their work, and that of Charles Kindleberger (1973), Peter Temin (1976, 1989), Barry Eichengreen (1995), and many other scholars focusing on particular aspects of the contraction, has done much to clarify the causes and consequences of the collapse, and to clarify the policy mistakes made by the Federal Reserve System. Nevertheless, the flood of books and papers on monetary problems during the Depression shows no signs of abating, suggesting that we have not yet reached the point where we believe that existing explanations are entirely sufficient.

This is especially the case when we turn to the causes of the collapse of the banking system. Important advances have been made in determining the role of panic as opposed to fundamentals. Yet there is perhaps still room for an attempt to provide a narrative framework for understanding the crisis. Here I will argue that the banking crises of the early 1930s were similar to the "twin crises" - banking and balance of payments crises - that have occurred in developing countries in recent years. The rural regions of the United States were like the developing countries today: dependent on the export of a few commodities in which they had a comparative advantage, and with independent, and relatively weak banking systems. Declining demand and export prices after 1929 weakened the banking systems in rural regions because they raised doubts about the ability of bank borrowers to repay their loans, and led to balance of payments deficits. Since the banks in rural regions were linked by fixed exchange rates to separate banking systems in more developed regions, there was a 
natural desire, moreover, on the part of people who had deposits in rural banks to move their funds to stronger banks in the financial centers, a capital flight. The interregional movement of funds further weakened the banking system in the regions experiencing the "external" drain. Eventually, as bank failure rates rose, runs developed. In the end, governments intervened by imposing restrictions on withdrawals. ${ }^{2}$

To be sure, the analogy between the "twin crises" in developing countries and the banking crises of the 1930s can be taken only so far. The crises in developing regions today have involved elements, such as short term capital flows and currency mismatches that we do not find among regions of the United States in the 1930s. Most developing countries, moreover, can devalue their currencies relative to others. This option was not open to regions within the United States. Minnesota dollars were not going to be reduced to .75 in New York dollars. Nevertheless, the analogy with the twin crises of recent years, I believe, helps provide a vocabulary for understanding the banking crises in the early 1930s. This paper, in other words, examines the banking crises from a regional perspective. It attempts to demonstrate that there were important forces at work that have been somewhat neglected because they do not show up clearly when the problem is viewed from a purely macroeconomic or purely micro-economic perspective. ${ }^{3}$

Although regional aspects of the Depression have been neglected in recent discussions of the monetary side of the contraction, with the important exception of Wicker (1996), regional differences were important to people at the time for a number of good reasons. (1) During the 1930s there were important cultural barriers to the mobility of labor. African Americans faced enormous racial discrimination wherever they went, and even white southerners were branded as lazy and inferior workers. As Gavin Wright (1996) has 
shown, while the labor markets of Birmingham England and Pittsburgh Pennsylvania were integrated, those of Birmingham Alabama and Pittsburgh Pennsylvania were not. (2) Banks were not permitted to branch across state lines, and often were prohibited from branching within states. Many banks in rural areas, therefore, had most of their resources tied up in assets that depended on the price of a single agricultural product. (3) Federal programs that transfer income from regions that are doing well to regions that are not, such as agricultural price support programs, did not exist on a modern scale when the depression began. (4) Monetary-policy was influenced strongly by the individual Governors of the Federal Reserve Banks. By design the District Banks represented the interests of separate regions, and were given far more power to adopt independent policy actions than is the case today. This was changing. Indeed, soon after the Federal Reserve was established it was recognized that open market purchases had to be coordinated by a system-wide committee because the interests of a particular district (to avoid the drain of reserves to central money markets produced by a purchase of securities) might differ from the interests of the system as a whole. But the tendency of governors from predominantly rural districts to see a conflict between what was good for their district and what was good for the eastern money markets persisted.

The experience of the United States during the early 1930s is unlikely to be repeated in detail. Nevertheless, it does throw into sharp relief some of the problems that face a monetary authority that must find the right path for a group of diverse regions when things go bad. Certain rural regions of the United States were hit especially hard by the downturn of 1929 because the prices of food, fibers, and minerals fell especially rapidly. The banking systems in those regions then experienced a silent, but nonetheless destructive loss of 
deposits because their rudimentary banking systems were linked by a common currency to powerful financial centers. Had policymakers been alert to the signs of interregional capital flight, they might have intervened successfully. Instead, the banking crisis was allowed to fester. Hopefully, this paper then may be of some relevance to the current debate over whether to extend existing monetary unions, and possibly to future debates about how to conduct monetary policy within a monetary union.

\section{The Role of Deflation}

The cyclical downturn that began in late 1929 (August, according to the NBER chronology) ushered in a strong downward trend in prices and income: The NNP deflator fell 4.6 percent between 1929 and 1930, and nominal NNP fell 16.1. ${ }^{4}$ The deflation, of course, was far from uniform. The prices of some of the major agricultural products dropped steeply in real terms. ${ }^{5}$ This is shown in Table 1 , which reports the real prices of some of the important agricultural products, real net farm income, and the real value of mineral products, starting in 1925 when the real prices of a number of these crops and real net farm income reached their postwar peaks. The real price of wheat experienced the most dramatic decline. It fell steadily year after year until by 1932 it had lost 60 percent of its 1925 value. The other series show a rebound in the late 1920s. So real net farm income reached another peak in 1929, although at a lower level than in 1925. Between 1929 and 1930, however, all of the key farm prices dropped in real terms, and real net farm income declined about 29 percent. Between 1929 and 1932 real farm income declined about 60 percent. Such a decline was bound to have enormous consequences for regions that were highly specialized in the production of basic agricultural products, and for banks in those regions because it raised serious questions about the ability of farmers to service their debts. 
The impact of these movements in real prices can be seen in the regional terms of trade shown in Table 2. The West North Central, a wheat-growing region, and the West South Central, a cotton-growing region, were hard hit. Perhaps somewhat more surprising are the substantial declines in the terms of trade of the Pacific and Mountain regions. The fall in mineral prices may be the explanation here. The price of silver fell from $\$ .53$ per fine oz. in 1929 to $\$ .28$ in 1932, a fall of 64 percent in nominal terms, and 38 percent in real terms (using the GNP deflator). ${ }^{6}$ The price of lead fell from about $\$ .068$ per pound in 1929 to $\$ .032$ in 1932, a fall of 76 percent in nominal terms, and 50 percent in real terms. The price of copper fell from $\$ .184$ per pound in 1929 to $\$ .058$ in 1932 a staggering fall of 115 percent in nominal terms, and 89 percent in real terms. There are, however, some surprises in the table. The South Atlantic region, for example, actually experienced an improvement in its terms of trade.

What caused the relative price shocks of the early 1930s? A boom-and-bust cycle associated with World War I is one candidate. The war added greatly to the demand for these basic commodities while destroying productive capacity in Europe. Farmers and businessmen in neutral countries, such as the United States, went into debt in order to expand capacity. Later demand declined to more normal levels, and supply expanded as European producers came back on line. The result was a decline in commodity prices that became a rout in the early 1930s. Barry Eichengreen's (2002) argument that the monetary shock was worldwide provides a second candidate: if the world shock was greater initially than the U.S. shock it would explain why the prices of internationally traded goods fell faster and farther than the prices of domestically traded goods. But to explain the origins of these relative price shocks in adequate detail would take us far a field. Kindleberger (1973, 
chapter 4, 83-107) provides a detailed commodity-by-commodity account going back to World War I. For our purposes it is sufficient to take these shocks as given.

How did the deterioration in the terms of trade and the contraction in income affect the stability of the banking system? Table 3 summarizes some information. The first column of data shows the cumulated amount of suspended bank deposits as a percentage of 1929 deposits. In other words, the figure for New England shows total suspended deposits from 1930 through 1933 as a percentage of total deposits in all commercial banks in the region in 1929. This column illustrates the wide regional differences in the experience of the crisis. Evidently, the regions containing the eastern financial centers (New England and Middle Atlantic) along with the Pacific Coast suffered the least damage.

The second column of data shows the percentage change in the terms of trade of each region - "the prices of goods sold by census divisions to other parts of the United States" divided by "the prices of goods bought by census divisions from other parts of the United States" - based on Warren Waite's (1942) estimates. This column shows that movements in interregional terms of trade were dramatic, but not always in the same direction as suspended deposits. ${ }^{7}$ In fact, the simple correlation between changes in the terms of trade and the amount of suspended deposits, shown in the last row of the column, goes the "wrong" way. ${ }^{8}$

The change in total personal income, shown in column 3 , goes directly to the question of how much income borrowers had with which to repay loans. This variable is correlated in the right direction with the amount of suspended deposits. The correlation, however, is far from perfect. The simple correlation between suspended deposits and personal income change, -.50 , is not statistically significant in such as small sample. Over all 
four years, for example, the South Atlantic region experienced the smallest fall in personal income, "only" 44.97 percent, but it experienced the second highest level of bank suspensions, 20.91 percent. The institutional advantage of containing the large money center banks evidently could offset, in some measure, the disadvantage of a large decline in personal income.

There were precedents for the deflation of the early 1930s. Prices and real incomes, including farm prices and real incomes, fell dramatically in the 1890s and after World War I. The deflation of the 1890s was associated with banking crises, particularly the crisis of 1893. The depression associated with the deflation and banking crises of the 1890 s was severe in terms of output and employment, although as Neal et al. (this volume) point out the deflation and banking crises may have produced reforms in the financial system that set the stage for more rapid economic growth. The post World War I deflation, on the other hand, did not produce anything like the crack-ups in the 1890s and early 1930s. One difference may be that rural regions were coming off of a long period of prosperity, and so the rural banking problems and capital flight we observe in the early 1930s did not emerge following World War I.

\section{Silent Runs and Noisy Runs}

There has been a tendency in the literature to focus on what might be called "noisy runs." Depositors literally run down to the bank, stand in line with their scared fellow depositors, and withdraw cash, perhaps forcing the bank to close its doors. Equally damaging to banks, and to the economy in a particular region, was a "silent run." Depositors simply write checks on a bank they consider weak and deposit them in another bank they 
consider stronger. Noisy runs lead naturally to a decline in the deposit currency ratio. This is one reason why Friedman and Schwartz, and subsequent authors, tended to focus on the deposit currency ratio as an indicator of distrust of the banking system. ${ }^{9}$ A silent run, by way of contrast, need not produce any change in the aggregate deposit-currency ratio. As I will try to show below silent runs of substantial magnitude seem to have preceded the noisy runs of the early 1930s. Silent runs are familiar from more recent banking crises, such as the savings and loan crisis, but their role in the Great Contraction has been neglected compared with the attention paid to noisy runs.

A silent run could be intraregional (the transfer of deposits from a small local bank to a bigger bank in a nearby city) or interregional (the transfer of deposits from a small bank in the interior of the country to a large bank in the Eastern financial centers.) Both drains create a liquidity problem for the bank losing deposits, and both types of run were important during the contraction. Here, however, I will focus on the interregional runs. First, interregional runs probably created more economic distress in the region losing funds. Borrowers, for example, may have been able to follow depositors when the run was intraregional, but not when it was interregional. Second, monetary policy during the contraction was controlled by the Governors of the Federal Reserve Banks. And finally, focusing on the interregional runs may provide some useful examples for current debates about dollarization and monetary unions.

There has been a good deal of attention paid in the literature to whether bank runs were sometimes the result of a "contagion of fear," that is a panic, or whether they always resulted from rational concerns about the solvency of banks. The latest research by Calomiris and Mason (1997, 2000), based on a large microeconomic sample of banks, 
suggests that a "contagion of fear" may not have been very prominent -- that the weakest banks experienced the most intense runs. A silent interregional run, almost by definition, is up to a point at least, a measured and rational response to concerns about the solvency of the banking system, and therefore also inconsistent with a "contagion of fear." It could be that fundamentals were misjudged, although given the subsequent course of events this would be a hard position to defend. And it could be that the people making the decision to move deposits were taking their clue from other people they regarded as informed and prudent, rather than looking themselves at fundamentals. Still, a run based on these considerations would be better described as a "demonstration effect," than as a contagion of fear.

At times the term panic is used to refer not so much to the behavior of individuals as to the behavior of the group. One can imagine events in which the behavior of each individual separately is rational even though the behavior of the group as a whole is selfdestructive. Someone yells fire in a crowded auditorium. Each individual separately takes the rational action of running straight for the exit. No one is running around in a random fashion. But the aggregate effect is to create a dangerous congestion at the exit. If people were disciplined and filed out in order, more lives could be saved. Perhaps this definition of a panic applies to the runs of the early 1930s. The decision to remove deposits from rural areas in the face of a sharp downturn in real agricultural prices and incomes may have been prudent from the point of view of each depositor taken separately, but the aggregate effect was to undermine the banking system in those regions.

To get a sense of the magnitude of silent interregional runs we can turn to the Gold Settlement Fund. The Fund (its name was changed to the Interdistrict Settlement Fund after the United States went off the gold standard) was the set of accounts that recorded the flow 
of funds among Federal Reserve districts. If a check was drawn on a bank in San Francisco and deposited in New York, the Gold Settlement Account would record the increase in the assets of the Federal Reserve Bank of New York, and the decrease in the assets of the Federal Reserve Bank of San Francisco. The accounts also showed, on separate lines, the effects of federal government transfers and external gold flows.

The accounts of the Gold Settlement Fund do not provide a complete record of interdistrict movements of funds because some interregional transactions might have been completed by shipping gold or cleared through private clearing arrangements. Although the Federal Reserve had hoped that its clearing facilities would quickly supplant private clearinghouses and correspondent relationships, private arrangements remained important in the 1920s and 1930s. In 1929, for example, clearings through private clearinghouses were nearly double clearings through the Federal Reserve System. (White 1983, 108-110). Many of the private clearings through clearinghouses, however, must have involved local transactions. In the long run, moreover, transactions that produced sustained increases or decreases in correspondent balances would probably give rise, as Hartland $(1949,396)$ contended to clearings through the Gold Settlement Fund. So it is safe to assume that the Fund provides a clear picture of the direction that private funds were moving, at least for the period we are examining. It should also be kept in mind that changes in the Gold Settlement Fund do not correspond directly to changes in bank reserves because other variables, such as bank borrowing from the Federal Reserve, will affect bank reserves.

Figure 1 shows a summary measure of the extent of interregional gold flows from 1926 to 1937: the sum of all regional gold outflows (equal to the sum of gold inflows from regions gaining gold) divided by the average of amount of gold in the Gold Settlement 
Fund. For example, if Minnesota and other rural districts lost $\$ 10$ in gold (while New York and other eastern districts gained \$10) and if there was on average \$100 in the gold settlement fund, the figure plotted would be $10 \%$. In other words, $10 \%$ of the gold stock had moved from one region to another during the year.

It is clear from the figure that there were extraordinary interregional movements of gold during the Great Contraction. There was little change in the denominator during the early years of the Depression so the spike is largely due to interregional gold flows. The picture in the post 1934 figure is complicated by the influx of European gold. The low level of the ratio in these years compared with those immediately proceeding reflects an increase in the denominator. ${ }^{10}$

How could these gold movements exceed the amount in the Fund, as they did from 1930 to 1932 ? It would seem, at first thought that the highest this ratio could go would be to one. Suppose that initially all the gold was held by one group of Banks designated A, while group B held none. If no new gold was deposited in the fund and all the gold held by A was transferred during the year to $\mathrm{B}$, the ratio would be one. To put the question differently, why didn't some districts simply run out of gold? One offset was the deposit of new gold in the fund from inflows of foreign gold, and domestic gold mining, which was revived in early 1930s. ${ }^{11}$ In addition, the Federal Reserve, may have exercised its authority to simply reallocate part of the Fund to Reserve Banks that were exhausting their accounts. The accounting justification was that district banks losing gold had their "participation" in the ownership of Federal Reserve Assets increased. The Fund, in other words, could act as lender of last resort to individual Reserve Banks. ${ }^{12}$ 
Figure 1 distinguishes between interregional gold flows resulting from private transactions and net gold flows, the sum of private and Federal government transactions. Clearly, net gold flows were always less than private gold flows. This means that, in general, gold flows produced by Federal government transactions tended to offset private gold flows and preserve the internal balance of payments. I had expected to find this result only during the later years of the Depression. New Deal programs such as agricultural price supports that produced transfers to rural areas became important after 1933. The data shows, however, that interregional Federal transfers helped to preserve the internal monetary union even in the period 1930 to 1932; Federal transfers were simply insufficient to offset the other forces undermining the banking system. ${ }^{13}$

What was causing these interregional gold flows? I believe that in large part they reflected the transfer of funds from banks in the interior to banks in the traditional financial centers, most importantly New York, but also Boston and Philadelphia, by deposit holders seeking greater safety for their funds. In some cases, the flow might have been the result of someone writing a check on a bank in one region and depositing it in a bank in another region. In other cases, the flow might have been the result of someone writing a check in order to purchase a security owned in another region. In either case, the transfers could be termed a silent run, or to use a term more familiar from discussions of international crises, a capital flight.

Some additional evidence is provided in Figure 2, which shows the flow of gold into the Eastern Financial Centers (the all important New York District, Boston, and Philadelphia) from 1926 to 1933 . Figure 2 throws the influx of funds in 1930, 1931, and 1932 into dramatic relief. Some inflow might have been expected because of changes in the 
terms of trade. If rural regions had to pay only slightly less for their imports, but got substantially less for their exports, they would, other things equal, run a balance of payments deficit. Figure 2 therefore shows the terms of trade between the Eastern Financial Centers and the rest of the country as an index, to be read against the right-hand axis, with 1926 $=100 .{ }^{14}$ The eastern terms of trade did improve somewhat during 1930 and 1931, and that might account for some of the inflow, although there is a sharp drop in 1932, while gold continued to flow in. Figure 2 also shows total personal income in the Eastern financial centers relative to total personal income in the remainder of the country, beginning in 1929 when the figures become available. ${ }^{15}$ This is also an index $(1929=100)$ to be read against the right-hand side. Eastern incomes it turns out rose steadily relative to those in the rest of the country during 1930-1932. Other things equal, the relative strength of income in the East would have drained funds from the East, because eastern exports would fall more than imports. So this factor was working in the direction opposite to the dominant flows and cannot explain them.

The effect of these movements, along with other factors such as the lending by Federal Reserve district banks to their members, can be seen in figure 3, which shows the growth of deposits by district between June 1929 and June $1930 .^{16}$ The dates here are important. The Gold settlement fund data shows end of year figures, and things were to deteriorate substantially between June and December 1930. Evidently, the experience varied dramatically from district to district during the first year of the contraction. ${ }^{17}$ Some had experienced substantial contraction; others had experienced substantial growth. New York, in particular had experienced a $15 \%$ gain in deposits. The districts have been arranged by total 1929 deposits from smallest (Minneapolis) to largest (New York). So the chart 
illustrates the tendency of deposits to move from the smaller, and therefore weaker, banking systems to larger, and therefore stronger, systems.

Figure 4 shows the following year, the change in deposits by region from June 1930 to June 1931 . The picture is now very different. What had been a retreat in some regions and an advance in others had become a general rout. Only San Francisco and Philadelphia were able to keep their heads above water. In most cases, the decline in deposits was due to both a decrease in reserves and to a fall in the deposit-currency ratio. New York, however, was an exception. It experienced a small increase in reserves.

We can also see the redistribution of funds if we look simply at the balance sheets of the four largest New York National Banks - First, National City, Chase, and Public. End-ofyear values for deposits, loans, and reserves of the Big Four are shown in Figure 5. All three categories were higher at the end of 1930 than at the end of 1929. The gains started in the late 1920s and were probably produced during that period by the boom in the stock market rather than banking difficulties in the interior. This may mean that there was an organic link between the stock market boom and the deterioration of the condition of the banks in the interior.

Who was moving their funds? It seems unlikely to me that individual depositors contributed very much to the interregional capital flight of the early 1930s by directly moving funds from one bank to another. Individuals might move their funds to a larger bank in the same city, or divide their funds among several banks, or purchase financial assets, or withdraw cash. They were unlikely, one would think, to move their funds to a bank in another district. It seems more likely that when funds were moved directly to a bank in a different district, they were in the main business or bank funds. It would be sensible for the 
chief financial officer of a nationwide corporation to move the working funds at a small local bank to a larger bank in a financial center, especially if that is where the corporate headquarters were located. It is possible that some of the funds in flight were bank funds. A bank that had traditionally divided the funds it held in other banks between regional centers and the Eastern financial centers might have shifted more of its funds to the latter as local conditions worsened.

Individuals would be involved, however, when the interregional transfer resulted from the purchase of financial assets on the stock exchange. The purchase of a government bond, for example, might lead to the removal of funds from a bank in the interior by the individual purchasing the bond, and their redeposit in a bank in the east by the person selling the bond. World War I, by creating a large widely held public debt, and by creating familiarity with the government bond market, may have contributed to the development of this channel for disintermediation and capital flight.

Although the capital flight has not received much attention in recent years, a number of careful observers noted it at the time. (1) E. A. Goldenweiser was the director of the Division of Research and Statistics of the Board of Governors of the Federal Reserve System during the contraction. In his retrospective assessment of the period Goldenweiser (1951, 164) cites two factors to explain the tide of bank failures: (1) "commodity price declines and shrinkage of real-estate values" and (2) "lack of confidence in the solvency of banks [that] resulted in large-scale withdrawals of deposits and in transfers of funds from smaller to larger banks, particularly to banks in reserve and central reserve cities." While Goldenweiser tends to discount actions that the Federal Reserve might have taken to end the 
crisis (and so to make the case for the advice that he gave at the time?) there is no reason to think that his account of the causes of the crisis was biased.

(2) James W. Angell was one of the leading monetary economists of the day and an original member of Roosevelt's Brain trust. In one study he (1969 [1936], 66-68) examined regional deposit data. There he noted the rise in New York and Philadelphia's shares of total deposits and attributed the increases to "interior funds seeking safety after 1929."

(3) Fred L. Garlock was an economist with the Bureau of Agricultural Economics of the Department of Agriculture. He conducted detailed studies of country banks in Arkansas (Garlock and Gile, 1935) and Wisconsin (Garlock 1941) that included interviews with bank officials as well as more conventional examinations of bank balance sheets and income statements. In his study of Wisconsin banks he noted $(1941,10)$ that there had been "a general movement of funds from agricultural areas to the large financial and industrial areas during the early 1930s." And he attributed this to an adverse balance of payments, and in 1932, although not before, to withdrawals for "hoarding or for transfer to other points where it was felt the funds would be more secure."

(4) Calvin Hoover and B.U. Ratchford $(1951,171)$ claimed that large insurance and railroad companies transferred working balances from small local banks in the South to larger, safer banks nearer their home offices.

More recently, Elmus Wicker $(1996,102)$ describes the problem under the term “seepage.” He notes: "Data on bank deposits show a general movement of funds from agricultural to financial and industrial centers during the Great Depression." As evidence he offers the decline in the ratio of nonmember bank total deposits to total deposits of all commercial banks, and the increase in the ratio of total deposits of 101 weekly reporting 
member banks to total deposits of all commercial banks. One advantage of the Gold Settlement Fund data is that rather than simply showing the ratio of deposits in two different kinds of banks, or two different areas, it shows dollars that we know were actually transferred from one region to another.

All in all, the evidence, although admittedly sketchy, suggests that we are dealing with a substantial drain of gold from the interior motivated by the search for deposit safety. From the point of view of the banks and regions losing the gold, of course, the liquidity problems are the same whether the loss was due to a capital flight or to a balance of trade deficit.

A capital flight to the East is the opposite of the traditional picture of drain on the East produced by banks in the South and West drawing on Eastern correspondents, the picture made famous by Sprague (1968 [1910]) in his classic history of bank failures under the National Banking Act. It would be surprising if we could not find individual examples of banks in the interior that were under pressure from depositors liquidating deposits held in eastern banks during 1929 to 1932 . So again the eastern movement of funds remains hard to explain in the absence of a capital flight. Perhaps what had changed from an earlier day, was the growth of national corporations with the ability to move funds from one region to another, and growth of widespread holdings of government bonds that could be liquidated (on eastern markets) in an emergency, a point I will return to below.

How significant were these flows for the system as a whole? One metric is bank reserves. In 1929 bank reserves outside New York totaled $\$ 1.405$ billion. The net flow of gold toward New York averaged about 36 percent of this amount. Partly these private flows were offset by gold flows resulting from federal taxes and expenditures. Then as now, more 
taxes were collected in the eastern financial centers than were spent there. Partly also these flows were offset by loans extended by the various Federal Reserve banks. Nevertheless, the net flow of gold must have placed a severe burden on banks in other regions, and helped intensify the crisis.

To clinch the argument that silent runs undermined the banking systems in the interior regions and contributed to the banking crises it would be necessary to show in detail how losses of deposits due to interregional transfers affected individual banks. And this I must confess, I have not done. That real harm was done is, I would argue, plausible. The story would be, essentially, the usual textbook story of a multiple contraction of loans and deposits. Borrowers who could not renew loans or borrow working capital would be forced to default, undermining the solvency of their lender, and creating deterioration in local economic conditions that would undermine other banks. But I have no ground level examples of banks that actually experienced this sequence of events. It is possible, as a matter of arithmetic, that the banks that lost reserves due to the interregional capital flows were the ones that survived the crisis.

A natural question to ask, for someone seeking confirmation that the capital flight mattered, is whether the interregional gold flows produced liquidity effects on interest rates. In other words, did rates rise in regions losing gold relative to regions gaining gold? The answer, it must be admitted, is no. Gene Smiley (1981) and Howard Bodenhorn (1995) estimated bank loan rates by region, and their series do not reveal distinct liquidity effects from the gold flows in the first half of 1930. On a regional level, this is the same finding -declining interest rates in the face of a declining stock of money -- that was at the center of Peter Temin's critique of Friedman and Schwartz's interpretation of the Depression. 
Evidently, the demand for loans was declining rapidly, even as losses of deposits deprived banks of the ability to make them. Real rates, of course, were rising rapidly. For example, the nominal loan rate for country national banks in the West North Central region, a wheatgrowing region, was 7.58 percent in 1929 and 7.04 percent in 1930. No evidence here of a liquidity effect. ${ }^{18}$ But the "wheat rate of interest" was 3.65 percent in 1929 and 51.96 percent in $1930 !^{19}$

To form a complete picture of the banking crisis one must move from the silent runs to the noisy runs, and the bank failures. This part of the story, however, has been well-told elsewhere, most recently, and most thoroughly by Wicker (1996). The first banking crisis, according to Wicker, was associated with the failure of a chain of banks, the Caldwell banks, headquartered in St. Louis. The St. Louis district was hit hard by the deflation and the collapse of agricultural incomes. But the high rate of failure in this region was also due to factors specific to the Caldwell banks, and it would not do to exaggerate the correlation that existed at this stage in the crisis between specific events and the deflation. While the St. Louis district experience a momentous decline in personal income between 1929 and 1930, other districts such as Dallas experienced a similar decline, but did not suffer to the same extent in the first noisy crisis. The right metaphor might be a cloth stretched to the breaking point. All of the cloth is under pressure, but where the first tear occurs will depend on particular structural weaknesses.

Wicker details the growing crisis, but the exact roles played by deflation, declining income, bank insolvency, fear itself, and so on are in doubt. Wicker, for example, suggests that Britain's departure from gold in September 1931 might have undermined confidence in the U.S. banking system by creating the fear of an external drain of gold, the more familiar 
analog of the interregional drains highlighted here. But in the nature of things he is unable to uncover evidence of a direct link between that event and the particular failures that followed in the United States on the heels of the British decision. Although there was some improvement in 1932 over 1931, bank failures and deposits in failed banks remained at very high levels, and the supply of money and bank credit contracted dramatically.

\section{The Banking Holidays}

Inevitably, governments intervene when financial crises become sufficiently severe. On the international scene intervention may take various forms: central banks may act as lenders of last resort, currency pegs may be abandoned, and capital controls may be imposed. In the early 1930s local and state government intervened by declaring "bank holidays." During the holidays depositors were prevented from making withdrawals from banks, or the amount that they could withdraw at one time was limited in some fashion, say to five percent of the account per month. ${ }^{20}$ There were several rationales. In most cases the banks were suffering heavy withdrawals. The goal was to protect the remaining assets while loans were arranged from the Reconstruction Finance Corporation, the Federal Reserve, or private lenders. In many cases, state and local officials also felt pressured into declaring holidays because holidays had already been declared in neighboring states. If depositors couldn't get cash in one state they might turn to banks in neighboring states. Our earlier discussion of silent runs suggests that this was a reasonable fear. There was probably also the hope that a "cooling off" period would allow the banks to reopen without suffering panicky withdrawals. 
The rash of bank holidays was clearly a sign of how bad things had got. Whether the holidays made things better or worse is a more difficult question. When we discuss a more conventional bank panic we note that an action that is separately sensible - get your money out of a weak bank - leads to actions that in the aggregate undermine the system. The same was true with the bank holidays. Actions that were rational in a given state had an external effect and led to a rash of holidays, accurately labeled a panic, which undermined the payments system in the aggregate.

Table 3 chronicles the state and local bank holidays. I do not make any claim that this list is complete. I put it together mainly from a perusal of the New York Times and the Financial Chronicle simply to enable one to get a sense of the timing and regional diffusion of the crisis. It is clear from the table that the holidays began in the regions that had lost reserves earlier because of price and confidence shocks. The first signs were municipal holidays declared in the upper Midwest. On November 1 came the first statewide moratorium in Nevada, and on February 12, a one-day holiday in Louisiana. ${ }^{21}$ The final dissolution of the banking system was ushered in by the holiday declared in Michigan in mid-February. Most of the larger Michigan banks belonged to one of two holding companies. The smaller, the Guardian Detroit Union Group, was teetering on the edge of bankruptcy. A desperate effort was launched to save this group through a Reconstruction Finance Corporation loan combined with aid from the Ford interests. But the plan foundered on demands that the Reconstruction Finance Corporation hold adequate collateral for its loan and the unwillingness of Henry Ford to take part, Ballantine (1948). ${ }^{22}$

The final spurt of holidays was caused, in part, by the fear in some states that holidays in neighboring states would lead to unsustainable withdrawals in those states that 
dared to keep their banks open. Governor Ruby Laffoon of Kentucky, obviously a politician

of some imagination, spoke for many when he declared a bank holiday on March 1, 1933.

His proclamation, given below, also describes the nature of the restrictions typically

imposed.

Whereas many banks in the cities and towns contiguous to the borders of the State of Kentucky are closed or are only permitting limited withdrawals of their deposits.

Whereas, a result of this situation will be that the funds of the banks of Kentucky will be withdrawn to supply the needs of these other communities, thus weakening the resources of the people of the Commonwealth, and,

Whereas legal holidays may only be declared in the State of Kentucky by the Governor appointing certain days as days of thanksgiving.

Now, therefore in consideration of the nation-wide banking situation and in view of the fact that the people of the State of Kentucky, though suffering from the general depression, may perhaps in comparison with the people of other states have reason for thanksgiving.

I as Governor of the State of Kentucky, appoint the days of March 1, 2, 3 and 4 1933, as days of thanksgiving in the State of Kentucky and declare such days legal holidays and do further provide as follows:

(1) That during said holidays all banks and trust companies shall be closed in the State of Kentucky for the regular transaction of business except.

(a) Said banks and trust companies may during the ordinary business hours of said holiday pay to their depositors (whether time or demand) not exceeding an aggregate of $5 \%$ of the respective deposits of such depositors at close of business on Feb. 28, 1933, provided that such payments shall only be made on checks, drafts or receipts dated subsequent to Feb. 28, 1933.

(b) During the banking hours of the last three days of the holiday period, said banks and trust companies may accept new deposits but such deposits shall be held in trust funds and may be insofar as they are represented by deposits of cash, withdrawn in full during said period.

(c) During said holiday period, said banks and trust companies, may transact any and all other business which does not involve the paying out of deposited funds other than herein authorized.... (Commercial and Financial Chronicle, March 4, 1933, 1484-85). 
It is obvious from table 3 that by late February or early March 1933 a large fraction of deposits had been restricted by official actions and a good portion of the remainder had been restricted in some measure by individual bank actions. Table 4, makes this point in a different way by showing a snapshot of the banking system on the eve of President Roosevelt's announcement of the national banking holiday: virtually all deposits in the country were subject in some measure to restriction.

The rapid diffusion of the bank holidays also raises the question of whether it would be correct to speak of a bank-holiday "panic" or a "contagion of fear." Again, much depends on how we define these terms. If what we mean by panic is simply foolish unreasoning behavior, then this was not the case. Governor Laffoon, at least, was clearly nobody's fool. His concern, that banks in Kentucky would be drained of gold if they remained open while other systems closed, was reasonable in the circumstances, although whether this drain would actually have happened is hard to say. On the other hand, if what we mean by panic is a situation in which people are making rational decisions that create negative externalities, and that could be channeled into a more socially responsible direction by alternative institutional arrangements, then it is reasonable to speak of a bank-holiday panic. If governor Laffoon and the other politicians declaring holidays could have been dissuaded from issuing these proclamations by promises of lender of last resort loans to the banks in their jurisdiction from the Federal Reserve, the ultimate breakdown of the payments mechanism might have been avoided. The chain leading from deflation to silent runs to noisy runs to bank holidays might have been interrupted by the Federal Reserve at many points. Early on the Federal Reserve could be excused for failing to act because the underlying process was 
hard to recognize, but surely when bank holidays erupted the case for vigorous action was clear.

Barry Wigmore (1987) suggests that the final denouement, the national bank holiday, was also due to the fear that President Roosevelt would take the United States off the gold standard. This fear, according to Wigmore, produced an external gold drain, which determined, at the least, the timing of the national holiday. As with Wicker's suggestion that Britain's departure from gold in September 1931 had repercussions for American banks, the external drain in 1933 created problems for eastern banks similar to those faced earlier by banks in the interior experiencing a drain to the eastern financial centers.

\section{Regional Aspects of the Conflict Over Monetary Policy}

As is well known, there was a divide, partly along regional lines, within the Federal Reserve between those who favored aggressive open market operations and those who thought that large-scale open market purchases would be futile or counterproductive. The former group included, at times, the governor of the influential Federal Reserve Bank of New York, and the latter included most of the governors of the other district banks, including the governor of the influential Chicago bank. It is natural, therefore, to ask whether the interregional balance of payments problems discussed above played a role in undermining support for open market purchases.

The opposition to open market operations undoubtedly reflected psychological predispositions and political infighting. As Friedman and Schwartz $(1963,415)$ astutely noted: "The other Banks [other than New York] were much more parochial in both situation and outlook, more in the position of reacting to financial currents originating elsewhere, 
more concerned with their immediate regional problems, and hence more likely to believe that the Reserve System must adjust to other forces than that it could or should take the lead." And as Friedman and Schwartz also noted, regional banks could assert their independence by opposing the policies advocated by the New York Federal Reserve.

But the governors did have to provide an intellectual justification of some sort for the positions they took and they were influenced in some measure by ideas. One episode discussed at length by Friedman and Schwartz $(1963,370-74)$ is particularly revealing. In July 1930, George L. Harrison, Governor of the Federal Reserve Bank of New York, wrote to the governors of the other district Banks asking for support for a policy of open market purchases. ${ }^{23}$ The reason he needed their support is simply that the power to make decisions regarding open market operations had recently been placed in the hands of the Open Market Policy Committee, which consisted of the 12 Governors of the Federal Reserve Banks. The Committee had held its first meeting in May 1930. Harrison, in other words, had to persuade a majority of his fellow governors to support a policy of buying government bonds in the open market, if the United States was to follow an expansionary open market policy.

Only two governors supported open market purchases: the Governors of the Richmond and Atlanta Banks. Those happen to be the two districts that had witnessed the largest decreases in deposits, so to this limited extent there is some support for the notion that opposition or support was based on the district level experience. (Figure 3 shows the picture of the districts shortly before Harrison called on the other governors for support.) But the list of opponents of open market purchases also included Governors in districts that had already begun to experience a loss of deposits, including Chicago, the second largest Bank in the system. Most of the opponents justified their opposition to open market operations 
with what might be characterized as versions of the real bills doctrine: the idea that monetary policy should simply accommodate to the needs of trade. This doctrine, always congenial to bankers, had to some extent been institutionalized at the Federal Reserve Board, as Allan H. Meltzer has shown, in a relatively sophisticated version that Meltzer dubbed the Burgess-Riefler doctrine. (Wheelock 1998; Meltzer, 2002). The views of some of the Governors, however, seemed to reflect relatively primitive versions of the doctrine: (1) that low levels of nominal interest rates were proof that credit was already abundant, or simply (2) that open market operations intended to buoy the economy were attempts at tampering with supply and demand. ${ }^{24}$

Several of the governors expressed concerns that open market operations at that time would reignite speculation. Frederic H. Curtiss, the chairman of the Boston Bank "expressed strong opposition to further purchases on the grounds that they were likely to feed the stock market rather than the bond market" (as summarized by Friedman and Schwartz, 1963, 373). James McDougal, Governor of the Chicago Bank, the second largest in the system, warned that if open market purchases were made "speculation might easily arise in some other direction" (as quoted by Friedman and Schwartz, 1963, 371). And Lynn P. Talley of the Dallas bank seemed to refer with some bitterness to the failure of the Federal Reserve to stop speculation in 1929. Fear of reigniting speculation may seem fanciful in retrospect. The stock market (measured by the Dow Jones average) was then about 70 percent below its peak, and was about back to where was in 1924. Nevertheless, it is clear, if we are willing to take these Governors at face value, that this is what they believed. (Calomiris and Wheelock, 1998). 
As the contraction worsened, and as deposits in all regions began to shrink, support for open market operations grew among the governors, but McDougal of Chicago remained a persistent opponent. In one famous episode in 1932 he refused to allow the Federal Reserve Bank of Chicago to join in open market purchases. Since the New York Federal Reserve might then have run short of gold, McDougal's intransigence undermined the effort to continue open market operations begun in 1932. (Eichengreen 1992, pp. 30-31)

The fear of reigniting speculation may have been based simply on a general feeling that speculation was bad, and had produced the downturn. But it is possible that the fear of speculation was based on an understanding, perhaps intuitive, that a boom on Wall Street would attract funds from the interior, as had happened in 1928 and 1929, further weakening banks in the interior. One is then led to ask whether the Governors would have been more receptive to another policy, say cuts in required reserve ratios, that was less biased toward New York and Wall Street? Given their general conservatism, and their reliance on interest rates as the ultimate test of the ease or tightness of monetary policy, it seems unlikely. Nevertheless, it is probably fair to say that open market purchases, which were perceived as attracting money from the interior into New York, may have faced more difficulties in winning support than a policy that promised a more even geographical distribution of the benefits.

\section{The Banking Crises of the Early 1930s from a Regional Perspective}

The banking crises of the early 1930s seem to have much in common with the twin crises of recent years. In 1929-1930 the United States experienced a sharp cyclical decline in income that was especially severe in some of the agricultural regions because of decreases 
in the real prices of foods, fibers, and minerals. There was, moreover, a silent run on the interior banks, as corporations and banks moved funds to the eastern financial centers for precautionary purposes, and as institutions and individuals purchased non-bank assets held in the east. Banks in the rural regions therefore came under intense pressure. A number of failures, some of them large, occurred, but since the failures were concentrated among the banks that had taken undue risks in the twenties, their regional locus was somewhat idiosyncratic. Eventually, silent runs were joined by noisy runs as individual depositors, alarmed by the growing tide of bank closures, and by the continual decline in economic activity, began converting deposits into cash, producing a catastrophic contraction in the number of banks, and in the supply of money and credit. The final denouement was produced by a rash of bank holidays declared by local and state governments that restricted the convertibility of deposits into cash.

The absence of nationwide branch banking has been pointed to as an important structural weakness that lay behind the banking crisis (White, 1984). The analysis presented here strengthens that conclusion. If the banks in the interior had been branches of major banks with home offices in the eastern financial centers the story might have been very different. Lending might have been curtailed in the interior and branches closed, as in Canada. $^{25}$ (Bordo, Rockoff, Redish, 1994). But there would have been no incentive for corporations to move working balances from the interior to the financial centers. In developing this argument it is important to distinguish between intraregional branching and interregional branching. The problem for the interior banks was not so much that they were small banks, although that didn't help, but rather that they were separated from the banks in the financial centers. When fears of bank illiquidity and insolvency increased, depositors 
tried to protect themselves by moving funds outside the affected regions. Partly, the decision to move funds must have been based on the assumption that banks in the financial centers held safer, better diversified portfolios of assets. But the decision may also have been based simply on the assumption that banks in the financial centers were more sophisticated about financial matters, and therefore better able to cope with uncertain times. The banking situation, to put it somewhat differently, would not have been very different even if their had been widespread intraregional branching, only interregional branching would do. Even a large bank with branches throughout the wheat-growing region of the Middle West, for example, might have fallen under a cloud and been subject to runs in the early 1930s when the real price of wheat was falling 60 percent. Only a bank with branches in both the Middle West and the eastern financial centers could hope to whether the storm.

It is always possible, one must admit, that if interregional branching had been widespread things might have gone wrong in another way. Recent evidence (Carlson 2001), suggests that in the 1930s banks with branches were more likely to fail rather than less likely, because the banks with branches had assumed more risk than banks without branches. There was no banking across state lines in the 1930s, but Carlson's data does include California, where banks could branch across different economic regions. So it is possible that had cross state branching been permitted, banks would have assumed riskier postures in the 1920s, and concern about bad loans in the interior in the early 1930s might have undermined confidence in and led to the closure of some very large banks. We can't be sure. But the collapse of the system might have been avoided had interregional branch banking been the norm, and if the collapse had occurred, it would have followed a very 
different path from the one actually followed, and might have generated a more appropriate policy response.

The regional nature of the crisis, especially during the early going, may have contributed to the failure of the Federal Reserve to respond effectively to the crisis. The one plan then seriously under consideration that might have alleviated the pressure on the banking system was the proposal by the Federal Reserve Bank of New York that the Federal Reserve System buy bonds on the open market. The Governors of the other district Banks, however, vetoed large-scale open market operations. Their opposition stemmed from a variety of factors, including their reliance on a version (in some cases a rather crude version) of the real bills doctrine. From their viewpoint, moreover, open market purchases may have appeared to be a region-specific medicine, likely to reignite speculation on the stock market, but unlikely to pay real dividends elsewhere. While we can fault the Federal Reserve for failing to engage in open market operations in response to the general contraction of income, it would be unreasonable to criticize it for failing to see the warning signs in the interregional gold flows. The Federal Reserve was a young institution and these were unprecedented gold movements. Nevertheless, it is interesting to recognize that had these been international rather than interregional flows, they would have excited considerable interest.

There was a time when it would have appeared foolish to worry about the recurrence of a crisis caused by a combination of depression, deflation, and a balkanized banking system. In recent years, however, deflation -- already a fact of life in Japan -- has loomed on the horizon for the United States and the European Monetary Union. And while the banking system of the United States has been increasingly linked together through nation wide 
branching, the European Monetary Union is still far from having a unified banking system. The present analysis then, may serve as a cautionary tale showing how a banking-balanceof-payments crisis can develop with great rapidity and virulence within what seems on the surface to be a sound, progressive banking system. 
Table 1. Real Prices of Agricultural Commodities, and Real Farm and Mineral Income, 1925-32

\begin{tabular}{|c|c|l|l|l|l|c|}
\hline & $\begin{array}{l}\text { Price of } \\
\text { Wheat per } \\
\text { bushel }\end{array}$ & $\begin{array}{l}\text { Price of } \\
\text { Cotton per } \\
\text { pound }\end{array}$ & $\begin{array}{l}\text { Price of Raw } \\
\text { Corn per } \\
\text { bushel }\end{array}$ & $\begin{array}{l}\text { Price of Beef } \\
\text { Steers Per } \\
\text { Pound }\end{array}$ & $\begin{array}{l}\text { Net Income } \\
\text { of Farm } \\
\text { Operators } \\
\text { from } \\
\text { Farming per } \\
\text { Farm }\end{array}$ & $\begin{array}{l}\text { Total Value } \\
\text { of Mineral } \\
\text { Products }\end{array}$ \\
\hline 1925 & 100 & 100 & 100 & 100 & 100 & 100 \\
\hline 1926 & 89 & 74 & 105 & 93 & 88 & 110 \\
\hline 1927 & 84 & 77 & 124 & 114 & 87 & 100 \\
\hline 1928 & 80 & 86 & 122 & 139 & 90 & 95 \\
\hline 1929 & 72 & 82 & 114 & 134 & 92 & 104 \\
\hline 1930 & 57 & 61 & 91 & 115 & 67 & 88 \\
\hline 1931 & 44 & 44 & 55 & 96 & 59 & 65 \\
\hline 1932 & 40 & 37 & 63 & 90 & 40 & 57 \\
\hline
\end{tabular}

Note: the NNP deflator was used to deflate all prices and farm and mineral incomes.

Sources: U.S. Bureau of the Census (1975): series E123 (wheat), E126 (cotton), K504 (corn), K585 (beef), K260 (farm income), and Friedman and Schwartz (1983, table 4.8, column 4, p.124) (NNP deflator). 
Table 2. Terms of Trade by Census Divisions of the United States, 1925-1932 (1925=100)

\begin{tabular}{|c|c|c|c|c|c|c|c|c|c|}
\hline & $\begin{array}{l}\text { New } \\
\text { England }\end{array}$ & $\begin{array}{l}\text { Middle } \\
\text { Atlantic }\end{array}$ & $\begin{array}{l}\text { East Nor } \\
\text { Central }\end{array}$ & $\begin{array}{l}\text { West } \\
\text { North } \\
\text { Central }\end{array}$ & \begin{tabular}{|l|} 
South \\
Atlantic
\end{tabular} & $\begin{array}{l}\text { East So } \\
\text { Central }\end{array}$ & $\begin{array}{l}\text { West } \\
\text { South } \\
\text { Central }\end{array}$ & Mountain & Pacific \\
\hline 1925 & 100 & 100 & 100 & 100 & 100 & 100 & 100 & 100 & 100 \\
\hline 1926 & 96 & 97 & 100 & 105 & 96 & 94 & 102 & 102 & 105 \\
\hline 1927 & 98 & 97 & 105 & 106 & 101 & 99 & 89 & 102 & 96 \\
\hline 1928 & 99 & 94 & 105 & 112 & 101 & 102 & 89 & 104 & 90 \\
\hline 1929 & 98 & 95 & 110 & 109 & 96 & 98 & 87 & 107 & 91 \\
\hline 1930 & 99 & 94 & 117 & 106 & 102 & 97 & 81 & 95 & 91 \\
\hline 1931 & 103 & 96 & 136 & 98 & 103 & 93 & 61 & 82 & 78 \\
\hline 1932 & 95 & 99 & 148 & 86 & 125 & 86 & 73 & 74 & 86 \\
\hline 1933 & 105 & 103 & 136 & 84 & 115 & 94 & 65 & 79 & 86 \\
\hline
\end{tabular}

Note. The regions are defined as follows. New England: Maine, New Hampshire, Vermont, Massachusetts, Rhode Island, and Connecticut. Middle Atlantic: New York, New Jersey, and Pennsylvania.

East North Central: Ohio, Indiana, Illinois, Michigan, and Wisconsin. West North Central: Minnesota, lowa, Missouri, North Dakota, South Dakota, Nebraska, and Kansas. South Atlantic: Delaware, Maryland, Dist. Of Columbia, Virginia, West Virginia, North Carolina, South Carolina, Georgia, and Florida. East South Central: Kentucky, Tennessee, Alabama, and Mississippi. West South Central: Arkansas, Louisiana, Oklahoma, and Texas. Mountain: Montana, Idaho, Wyoming, Colorado, New Mexico, Arizona, Utah, and Nevada. Pacific: Washington, Oregon, and California.

Source. Waite (1942). 
Table 3 Suspended Deposits, Terms of Trade, and Personal Income, by Region 1930-33.

\begin{tabular}{|c|c|c|c|}
\hline & $\begin{array}{l}\text { Suspended Deposits } \\
\text { (as a Percentage of } \\
1929 \text { deposits) }\end{array}$ & $\begin{array}{c}\text { Terms of } \\
\text { Trade } \\
\text { (Percentage } \\
\text { Change from } \\
\text { 1929) }\end{array}$ & $\begin{array}{c}\text { Total Personal } \\
\text { Income } \\
\text { (Percentage } \\
\text { Change from } \\
1929) \\
\end{array}$ \\
\hline New England & $6.00 \%$ & $6.94 \%$ & $-48.76 \%$ \\
\hline Middle Atlantic & 5.67 & 8.31 & -55.61 \\
\hline East North Central & 25.17 & 21.76 & -73.33 \\
\hline West North Central & 16.97 & -26.72 & -70.37 \\
\hline South Atlantic & 20.91 & 17.98 & -44.97 \\
\hline East South Central & 19.89 & -4.04 & -63.34 \\
\hline West South Central & 17.04 & -29.78 & -61.33 \\
\hline Mountain & 11.65 & -30.01 & -60.21 \\
\hline Pacific & 4.87 & -5.46 & -54.69 \\
\hline Correlation & & 0.15 & -0.50 \\
\hline \multicolumn{4}{|c|}{$\begin{array}{l}\text { Notes: See table } 2 \text { for the regions } \\
\text { Sources: Suspended Deposits: U. S. Board of Governors (1943, pp. 25-33, 285). Export } \\
\text { Prices: Waite (1942, table 10, p. 30). Personal Income: Schwartz and Graham (1956). }\end{array}$} \\
\hline
\end{tabular}


Table 3 State and Local Bank Holidays in 1932-33

\begin{tabular}{|c|c|c|}
\hline Date & State & Action Taken \\
\hline 17 October 1932 & Minnesota & Municipal holidays declared \\
\hline 1 November & Nevada & 12 day moratorium; twice renewed \\
\hline January 1933 & $\begin{array}{l}\text { Illinois } \\
\text { lowa }\end{array}$ & Small towns declare local holidays \\
\hline 20 January & lowa & One-day Holiday \\
\hline 4 February & Louisiana & One-day holiday \\
\hline 14 February & Michigan & $\begin{array}{l}\text { 8-day holiday, renewed until } \\
\text { federal holiday }\end{array}$ \\
\hline \multirow[t]{2}{*}{20 February } & New Jersey & $\begin{array}{l}\text { Legislature authorizes banking } \\
\text { commission to declare a } \\
\text { moratorium on February } 21 \text { this } \\
\text { power is exercised for one bank }\end{array}$ \\
\hline & Missouri & $\begin{array}{l}\text { One bank restricts withdrawals } \\
\text { after mayor declares moratorium }\end{array}$ \\
\hline 23 February & New Jersey & $\begin{array}{l}\text { Limited withdrawals authorized at } \\
\text { two banks }\end{array}$ \\
\hline \multirow[t]{3}{*}{25 February } & Maryland & $\begin{array}{l}\text { 3-day holiday, subsequently } \\
\text { extended }\end{array}$ \\
\hline & Ohio & Banks self-declare holidays \\
\hline & Missouri & $\begin{array}{l}\text { Banks granted right to restrict } \\
\text { withdrawals }\end{array}$ \\
\hline 28 February & $\begin{array}{l}\text { Indiana } \\
\text { Ohio } \\
\text { North. Kentucky }\end{array}$ & $\begin{array}{l}\text { Banks restrict withdrawals under } \\
\text { the authority of new banking laws }\end{array}$ \\
\hline 28 February & $\begin{array}{l}\text { Arkansas, } \\
\text { Pennsylvania }\end{array}$ & Banks initiate restrictions \\
\hline \multirow[t]{2}{*}{1 March } & Philadelphia and Pittsburgh & $\begin{array}{l}\text { Individual banks self-declare } \\
\text { holidays }\end{array}$ \\
\hline & $\begin{array}{l}\text { Kentucky } \\
\text { Mississippi } \\
\text { Tennessee }\end{array}$ & Bank holidays \\
\hline 2 March & $\begin{array}{l}\text { Alabama, California, } \\
\text { Georgia Louisiana Mississippi } \\
\text { Nevada, Oklahoma, Oregon, } \\
\text { Texas, }\end{array}$ & Bank holidays \\
\hline
\end{tabular}




\begin{tabular}{|c|c|c|}
\hline & $\begin{array}{l}\text { Utah, Washington } \\
\text { Wisconsin }\end{array}$ & \\
\hline 3 March & $\begin{array}{l}\text { Arizona, Georgia } \\
\text { Idaho, Illinois } \\
\text { New Mexico } \\
\text { North Carolina } \\
\text { Oklahoma, Virginia } \\
\text { Wyoming }\end{array}$ & Bank holidays \\
\hline 4 March & $\begin{array}{l}\text { Colorado, Delaware } \\
\text { District of Columbia } \\
\text { Florida, Georgia } \\
\text { Illinois } \\
\text { Kansas, Maine } \\
\text { Massachusetts } \\
\text { Minnesota } \\
\text { Missouri } \\
\text { Montana, Nebraska } \\
\text { New Hampshire } \\
\text { New Jersey } \\
\text { New York } \\
\text { North Dakota } \\
\text { South Dakota } \\
\text { Vermont }\end{array}$ & $\begin{array}{l}\text { Virtually all remaining banks closed } \\
\text { by governor's proclamations at the } \\
\text { request of Treasury officials. }\end{array}$ \\
\hline 6 March & United States & Bank Holiday \\
\hline
\end{tabular}


Table 4 State Bank Restrictions, Sunday, March 5, 1933

\begin{tabular}{|c|c|}
\hline State & Description of Restrictions \\
\hline Alabama & Closed until further notice \\
\hline Arizona & Closed until March 13 \\
\hline Arkansas & Closed until March 7 \\
\hline California & Almost all closed until March 9 \\
\hline Colorado & Closed until March 8 \\
\hline Connecticut & Closed until March 7 \\
\hline Delaware & Closed indefinitely \\
\hline District of Columbia & Three banks limited to $5 \%$; nine savings banks invoke sixty days' notice \\
\hline Florida & Withdrawals restricted to $5 \%$ plus $\$ 10$ until March 8 \\
\hline Georgia & Mostly closed until March 7, closing optional \\
\hline Idaho & Some closed until March 18, closing optional \\
\hline Illinois & $\begin{array}{l}\text { Closed until March } 8 \text {, then to be opened on } 5 \% \text { restriction basis for seven } \\
\text { days }\end{array}$ \\
\hline Indiana & About half restricted to $5 \%$ indefinitely \\
\hline lowa & Closed "temporarily" \\
\hline Kansas & Restricted to $5 \%$ withdrawals indefinitely \\
\hline Kentucky & Mostly restricted to $5 \%$ withdrawals until March 11 \\
\hline Louisiana & Closing mandatory until March 7 \\
\hline Maine & Closed until March 7 \\
\hline Maryland & Closed until March 6 \\
\hline Massachusetts & Closed until March 7 \\
\hline Michigan & $\begin{array}{l}\text { Mostly closed, others restricted to } 5 \% \text { indefinitely; Upper peninsula banks } \\
\text { open }\end{array}$ \\
\hline Minnesota & Closed "temporarily" \\
\hline Mississippi & Restricted to $5 \%$ indefinitely \\
\hline Missouri & Closed until March 7 \\
\hline Montana & Closed until further notice \\
\hline Nebraska & Closed until March 8 \\
\hline
\end{tabular}




\begin{tabular}{|c|c|}
\hline Nevada & Closed until March 8, also schools \\
\hline New Hampshire & Closed subject to further proclamation \\
\hline New Jersey & Closed until March 7 \\
\hline New Mexico & Mostly closed until March 8 \\
\hline New York & Closed until March 7 \\
\hline North Carolina & Some banks restricted to $5 \%$ withdrawals \\
\hline North Dakota & Closed temporarily \\
\hline Ohio & Mostly restricted to $5 \%$ withdrawals indefinitely \\
\hline Oklahoma & All closed until March 8 \\
\hline Oregon & All closed until March 7 \\
\hline Pennsylvania & Mostly closed until March 7, Pittsburgh banks open \\
\hline Rhode Island & Closed yesterday \\
\hline South Carolina & Some closed, some restricted, all on own initiative \\
\hline South Dakota & Closed indefinitely \\
\hline Tennessee & A few closed, others restricted, until March 9 \\
\hline Texas & Mostly closed, others restricted to withdrawals of $\$ 15$ daily until March 8 \\
\hline Utah & Mostly closed until March 8 \\
\hline Vermont & Closed until March 7 \\
\hline Virginia & All closed until March 8 \\
\hline Washington & Some closed until March 7 \\
\hline West Virginia & Restricted to $5 \%$ monthly withdrawals indefinitely \\
\hline Wisconsin & Closed until March 17 \\
\hline Wyoming & Withdrawals restricted to $5 \%$ indefinitely \\
\hline
\end{tabular}




\section{References}

Alston, Lee J., Wayne A Grove, and David C. Wheelock. 1994. "Why Do Banks Fail?

Evidence from the 1920s." Explorations in Economic History, Vol. 31 (4). (October): 40931.

Angell, James W. 1969 [1936]. The Behavior of Money: Exploratory Studies. New York: McGraw-Hill Book Company, Reprinted by Augustus M. Kelley,

Ballantine, Arthur A. 1948. "When All the Banks Closed." Harvard Business Review 26: $129-43$.

Bodenhorn, Howard. 1995. "A More Perfect Union: Regional Interest Rates in the United States, 1880-1960." In Michael D. Bordo and Richard Sylla, eds. Anglo-American Financial Systems: Institutions and Markets in the Twentieth Century. New York: Irwin Professional Publishing, New York University Solomon Center.

Brandt, Loren and Thomas J. Sargent. 1989. "Interpreting New Evidence about China and U.S. Silver Purchases.” Journal of Monetary Economics, Vol. 23 (January): 31-51.

Brunner, Karl and Allan H. Meltzer. 1968. "What Did We Learn from the Monetary Experience of the United States in the Great Depression?" Canadian Journal of Economics 1(May): 334-48.

Bordo, Michael D, Hugh Rockoff, and Angela Redish. 1994. "The U.S. Banking System from a Northern Exposure: Stability versus Efficiency." The Journal of Economic History. Vol. 54 (June): 325-41.

Calomiris, Charles W. and Joseph R. Mason. 1997. "Contagion and Bank Failures during the Great Depression: The June 1932 Chicago Banking Panic." American Economic Review, Vol. 87 (December): 863-83.

. 2000. "Causes of U.S. Bank Distress During the Depression," NBER Working Paper No. W7919, September.

Calomiris, Charles W. and David Wheelock. 1998. "Was the Great Depression a Watershed for American Monetary Policy?" in Michael D. Bordo, Claudia Goldin, and Eugene White (eds.), The Defining Moment: The Great Depression and the American Economy in the Twentieth Century. Chicago: University of Chicago Press, pp. 23-66.

Carlson, Mark. 2001 "Are Branch Banks Better Survivors: Evidence from the Depression Era?" No 2001-51 in Finance and Economics Discussion Series from the Board of Governors of the Federal Reserve System (U.S.).

Chandler, Lester V. 1970. America's greatest depression, 1929-1941. New York: Harper \& Row. 
Eichengreen, Barry. 1992. "Designing a Central Bank for Europe: A Cautionary Tale from the Early Years of the Federal Reserve System." In Establishing a Central Bank: Issues in Europe and Lessons from the US, eds. Matthew B. Canzoneri, Vittorio Grilli, and Paul R. Masson. Cambridge [England], New York: Cambridge University Press, pp. 13-33. 1995. Golden Fetters: The Gold Standard and the Great Depression, 19191939. New York: Oxford University Press. . 2002. “Still Fettered After All These Years,” NBER Working Paper, 9276.

Friedman, Milton. 1992. "Franklin D. Roosevelt, Silver, and China." Journal of Political Economy. Vol. 100 (February): 62-83.

Friedman, Milton and Anna J. Schwartz. 1963. A Monetary History of the United States. Princeton: Princeton University Press, for the NBER.

. 1970. Monetary Statistics of the United States: Estimates Sources, Methods. New York: Columbia University Press, for the NBER. . 1982. Monetary Trends in the United States and the United Kingdom. Chicago: University of Chicago Press for the NBER.

Fels, Rendigs. "Interregional Payments: A Comment." Quarterly Journal of Economics, Vol. 64, No. 3. (Aug., 1950), pp. 488-489.

Garlock, Fred L. "Country Banking in Wisconsin During the Depression." Washington D.C: U.S. Dept. of Agriculture, Technical bulletin no.777, 1941.

Garlock, Fred L. and B.M. Gile. "Bank Failures in Arkansas.” Fayetteville, Ark.: University of Arkansas, College of Agriculture, Agricultural Experiment Station, Bulletin no. 315, 1935.

Goldenweiser, E. A. 1951. American Monetary Policy. New York: McGraw-Hill.

Hartland, Penelope. "Interregional Payments Compared with International Payments." Quarterly Journal of Economics, Vol. 63, No. 3. (Aug., 1949), pp. 392-407. . 1950. "Interregional Payments: Reply." Quarterly Journal of Economics, Vol. 64, No. 3. (Aug., 1950), pp. 489-490.

Hartland-Thunberg, Penelope. 1950. Balance of Interregional Payments of New England. Providence, Brown University. 
Heim, Carol E. 1998. "Uneven Impacts of the Great Depression: Industries, Regions, and Nations." In The Economics of the Great Depression, ed. Mark Wheeler. Kalamazoo, MI: W.E. Upjohn Institute for Employment Research, 29-61. . “Interregional Payments: Reply." Quarterly Journal of Economics, Vol. 64, No. 3. (Aug., 1950), pp. 489-490.

Hoover, Calvin B. and B.U. Ratchford. 1951. Economic Resources and Policies of the South. New York: The Macmillan Company.

Kaminsky, Graciela L. and Carmen M. Reinhart. 1999. "The Twin Crises: The Causes of Banking and Balance-of-Payments Problems." American Economic Review. Vol. 89 (3) (June): 473-500.

Kennedy, Susan Estabrook. The Banking Crisis of 1933. 1973. Lexington: University Press of Kentucky.

Kindleberger, Charles P. 1973. The World In Depression, 1929-1933. Berkeley: University of California Press.

Meltzer, Allan H. 2002. "Chapter 5: Why Did Monetary Policy Fail in the Thirties?," unpublished manuscript, Carnegie Mellon University.

Miller, Victoria. 1998. "Banking Crises, Currency Crises, and Macroeconomic Uncertainty The Double Drain with a Cross-Border Twist: More on the Relationship between Banking and Currency Crises." The American Economic Review, Vol. 88, No. 2, Papers and Proceedings (May): 439-443.

Rawski, Thomas G. 1993. "Milton Friedman, Silver, and China." 1993. The Journal of Political Economy, Vol. 101 (1993): 755-758.

Rosenbloom, Joshua L., and William A. Sundstrom. 1997. “The Sources of Regional Variation in the Severity of the Great Depression: Evidence from the U.S. Manufacturing, 1919-1937.” NBER Working Paper 688, National Bureau of Economic Research, Cambridge, Massachusetts.

Smiley, Gene. 1981. "Regional Variation in Bank Loan Rates in the Interwar Years." The Journal of Economic History, Vol. 41, No. 4. (Dec.): 889-901.

Sprague, O.M.W. 1968 [1910] History of Crises Under the National Banking System. New York: A.M. Kelley.

Schwartz, Charles F. and Robert E. Graham, Jr. 1956. Personal Income by States since 1929. Washington, U.S. Govt. Print. Off..

Temin, Peter. 1976. Did Monetary Forces Cause the Great Depression? New York: Norton. 

1989. Lessons from the Great Depression. Cambridge: MIT press.

U.S. Board of Governors of the Federal Reserve System. 1943. Banking and Monetary Statistics. Washington, D.C., Board of Governors of the Federal Reserve System.

U.S. Bureau of the Census. 1975. Historical Statistics of the United States, Colonial Times to 1970, Bicentennial Edition. Washington D.C: GPO.

Waite, Warren C. 1942. "Indexes of the Terms of Trade between Areas in the United States." The Review of Economic Statistics, Vol. 24, No. 1. (Feb.): 22-30.

Wallis, John Joseph. 1987. "Employment, Politics, and Economic Recovery during the great Depression." Review of Economics and Statistics 69: 516-520.

Wheelock, David C. 1992. "Regulation and Bank Failures: New Evidence from the Agricultural Collapse of the 1920s." The Journal of Economic History. Vol. 52 (4). (December): 806-25. . 1998. "National Monetary Policy by Regional Design: The Evolving Role of the Federal Reserve Banks in Regional Federal Reserve System Policy." Federal Reserve Bank of St. Louis, Working Paper, 1998-010B

White, Eugene. 1983. The Regulation and Reform of the American Banking System, 19001929. Princeton: Princeton University Press. 1984. “A Reinterpretation of the Banking Crisis of 1930.” The Journal of Economic History 44 (March): 119-38.

Wicker, Elmus. 1996. The Banking Panics of the Great Depression. New York: Cambridge University Press.

Press. . 2000. Banking Panics of the Gilded Age. New York: Cambridge University

Wigmore, Barry. 1987. "Was the Bank Holiday of 1933 a Run on the Dollar Rather than the Banks?” The Journal of Economic History 47 (September): 739-56.

Wright, Gavin. 1996. Old South, New South: Revolutions in the Southern Economy Since the Civil War. Baton Rouge: Louisiana State University Press. 
Figure 1

Interregional Gold Flows, 1926-1937

(As a Percentage of Total Gold Held by the Gold Settlement Fund)

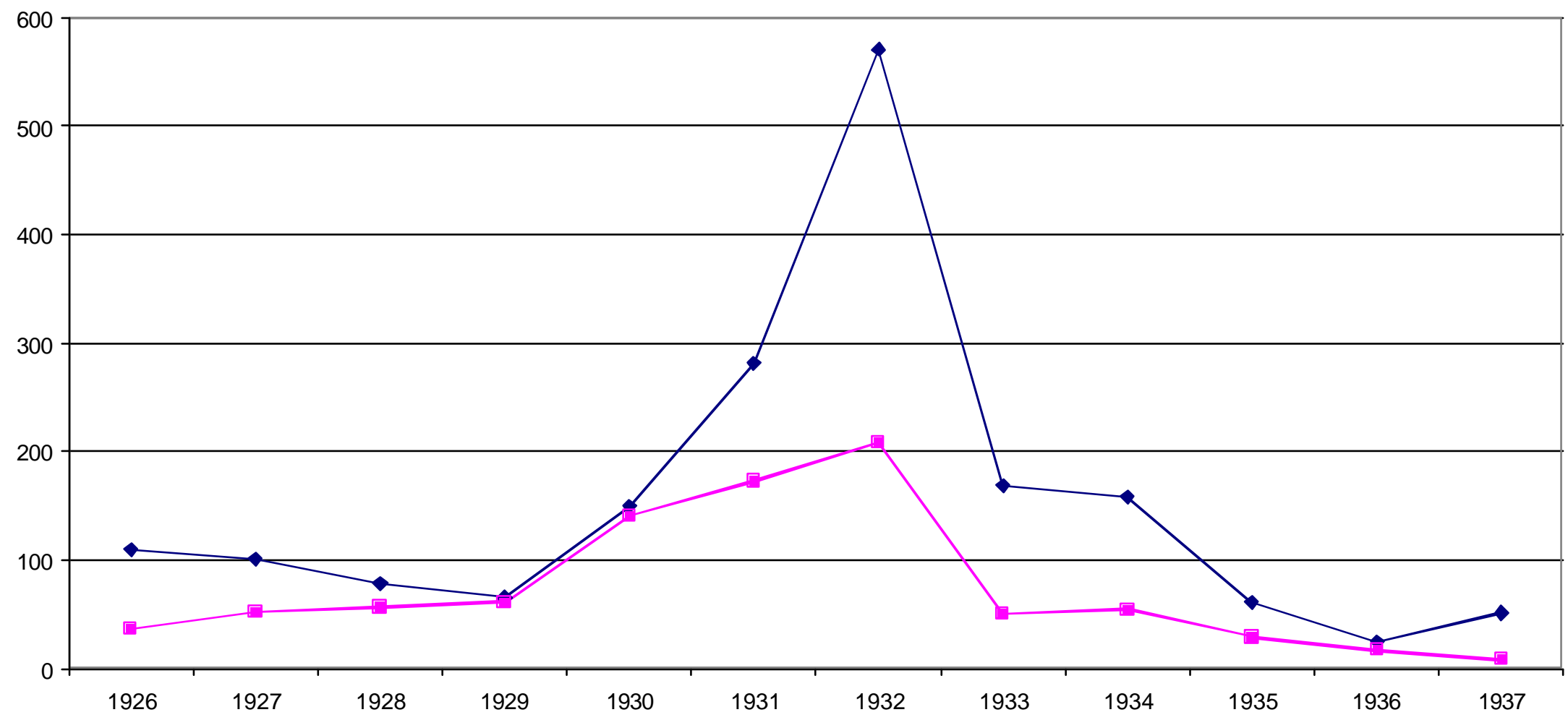

$\rightarrow$ Private Accounts $\rightarrow-$ Net 
Figure 2

The Flow of Gold to Eastern Financial Centers on Private Accounts, 1926-1933

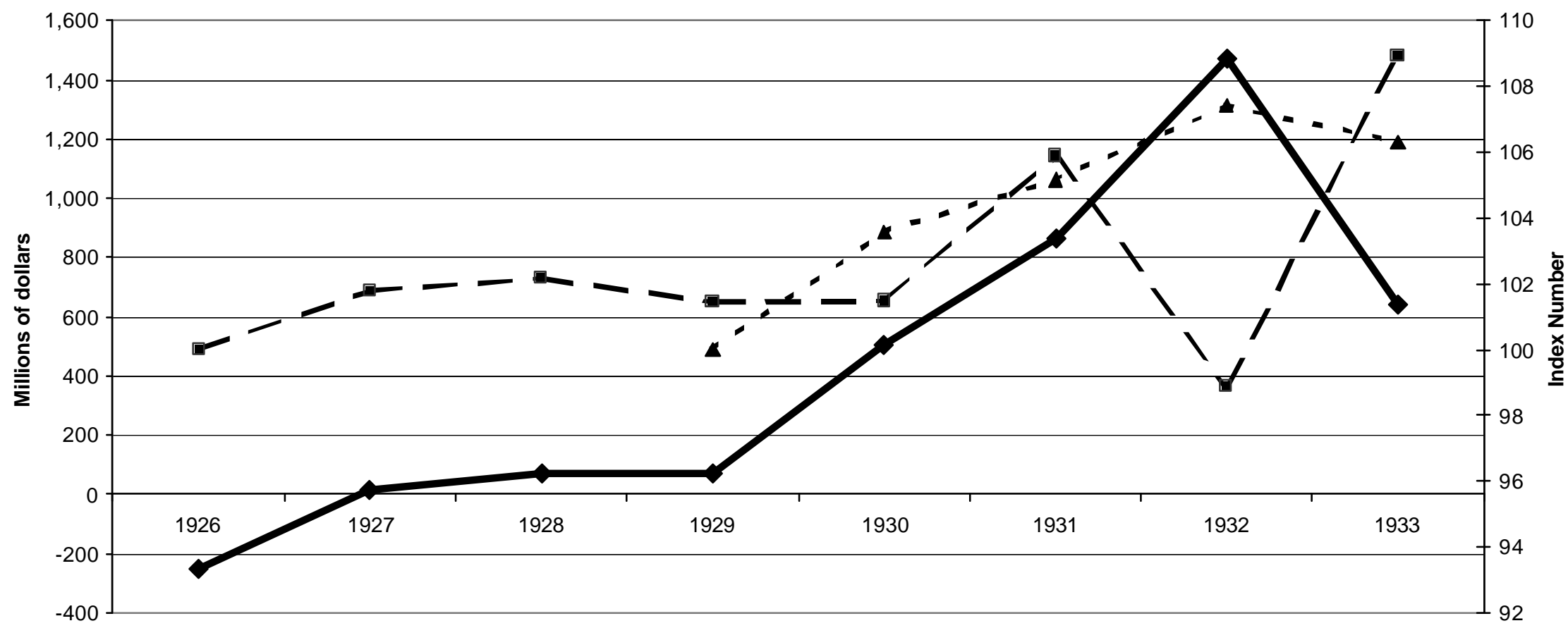

The Flow of Gold to Eastern Financial Centers - - Terms of Trade - 
Figure 3

Gains and Losses of Deposits by Federal Reserve District, 1929-1930

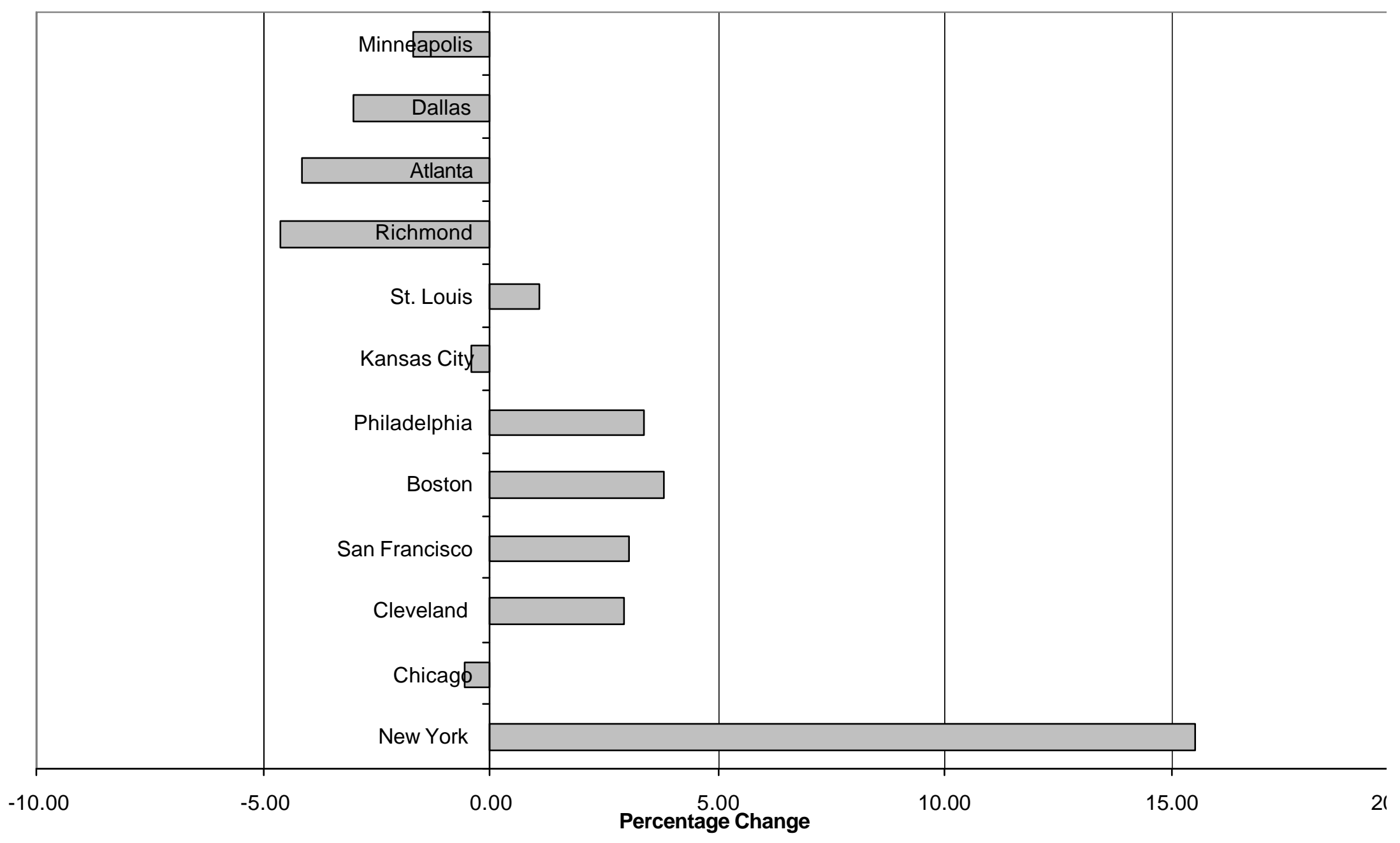


Figure 4

Gains and Losses of Deposits by Federal Reserve District, 1930-1931

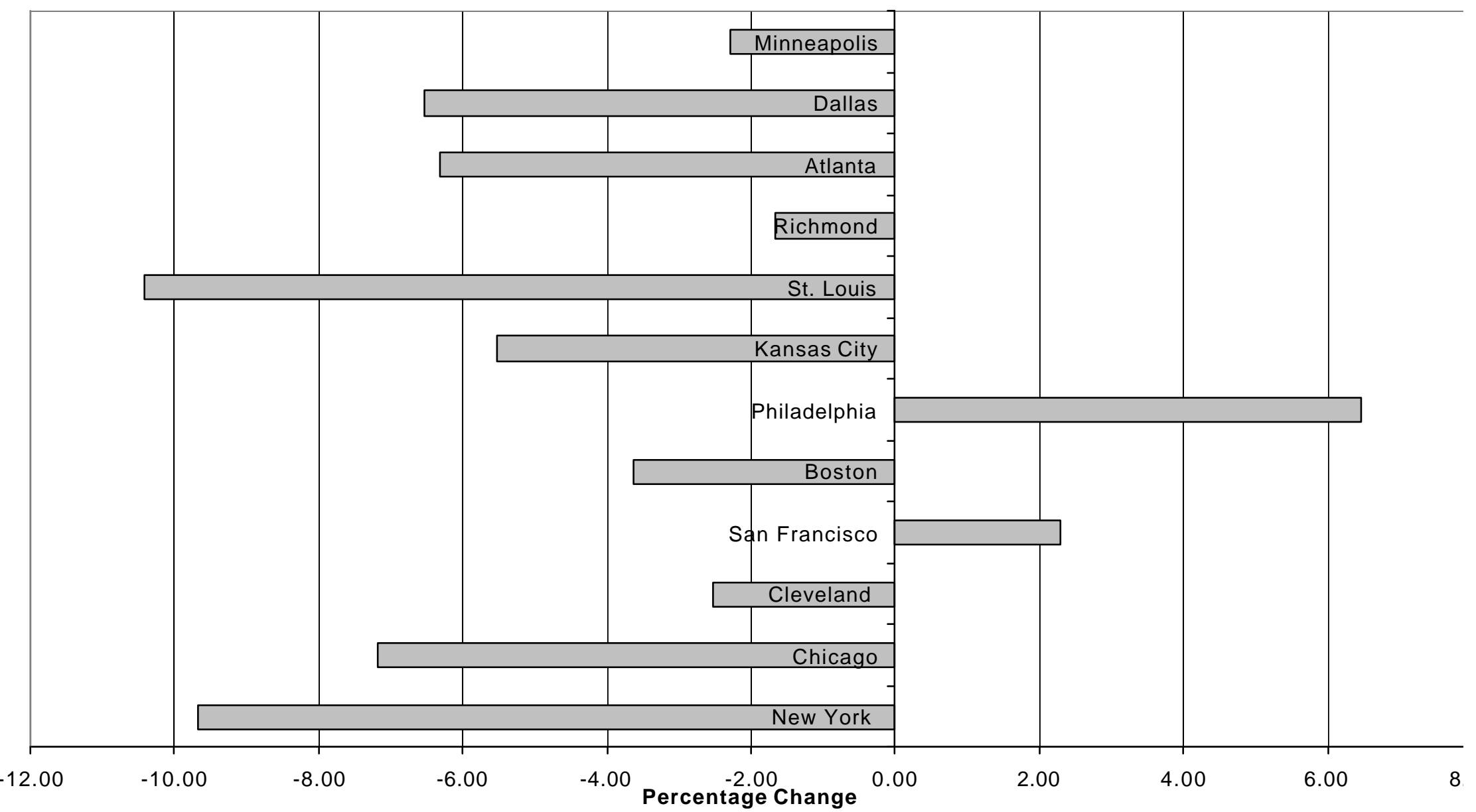


Figure 5

The Big Four New York Banks

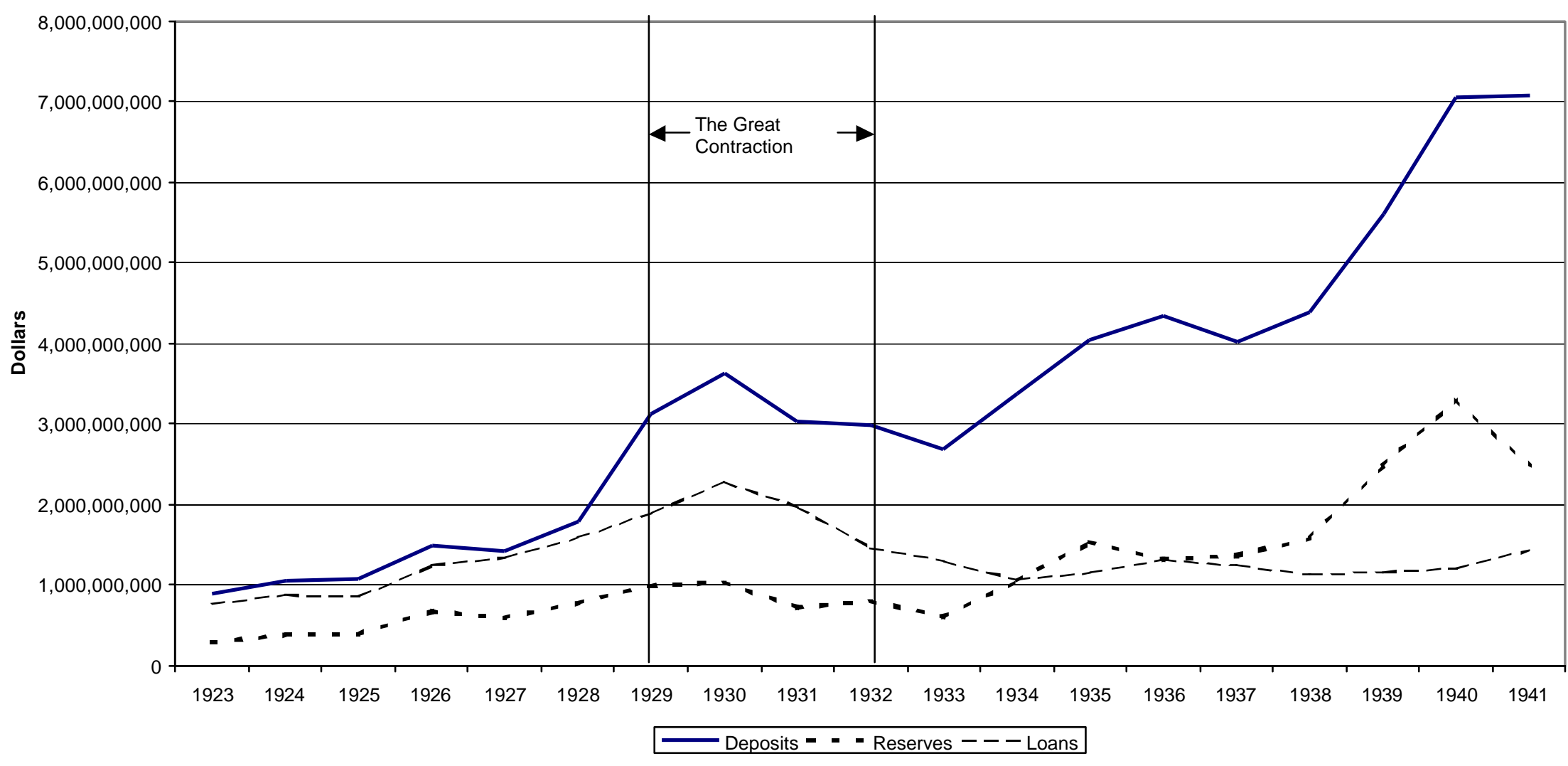




\section{Endnotes}

1. This paper was prepared for the Conference on the Anatomy of Deflations organized by Richard Burdekin and Pierre Siklos in conjunction with the International Economic History Association Meetings in Buenos Aires in 2002. Michael Bordo, Richard Burdekin, Kerry Odell, Pierre Siklos, Anna J. Schwartz, and Eugene White graciously provided comments on a previous draft. They are not to blame for the mistakes that remain.

2. There is a large literature on the "twin crises." Some papers that started me thinking about the analogy between the regional crises in the U.S. in the 1930s and more recent crises were Kaminsky and Reinhart (1998), Miller (1998), and Kaminsky and Reinhart (1999).

3. Scholars addressing real as opposed to monetary aspects of the depression, however, have frequently adopted a regional perspective: Wallis (1987), Rosenbloom and Sundstrom (1997), and Heim (1998).

4. The data are from Friedman and Schwartz (1983, p. 124)

5. Bank failure rates were high in rural regions in the 1920s, partly as a result of agricultural distress: (Wheelock, 1992; Alston, Grove, and Wheelock, 1994).

6. Roosevelt's Silver Purchase Program reversed the plunge in silver prices. This Program, which began in December 1933, and was accelerated under the Silver Purchase Act of June 1934, was intended to raise the price of silver, a boon to western silver producing states, and to increase the stock of money, through Treasury purchases of silver. As a result, the price of silver rose to a temporary peak of $\$ .64$ per fine oz. in 1935 . The price then slumped once more, although it remained above the depths of 1930-32 in both nominal and real terms. It has been claimed that the purchase program had a deleterious effect on China. (Friedman and Schwartz, 1963, 483-490; Brandt and Sargent, 1989; Friedman 1992; Rawski 1993).

7. Paul Rhode brought this data to my attention.

8. Calomiris and Mason (2000, 24), using their rich microeconomic data set, found mixed results from their agricultural variables. For example, monthly agricultural price change was significant in some, but not all regressions explaining bank survival rates. A greater presence of small farms had a negative effect on bank survival, but in their words the effect was not "highly significant or robust."

9. The deposit currency ratio is also, of course, a determinant of the stock of money, which Friedman and Schwartz consider the key variable.

10. We see some large private flows in the 1920-21 recession, if we extend the figure back to the early 1920s. These flows, however, appear to be a winding down of flows produced by the war. The net figures, moreover, show distinctly smaller interregional movements of gold, relative to the 
existing stock than in the early 1930s. The form of the accounts was changed, however, in 1926. And, I have not found a discussion of the pre-1926 accounts as thorough and authoritative as Hartland's (1949) discussion of the post-1926 accounts. So my reading of the early accounts is tentative.

11. Gold mining was an exception to the general trend in mining because the government fixed the nominal price. Thus, the real price of gold rose while the real price of other minerals fell.

12. The Settlement Fund accounts don't distinguish among the sources of additional gold. It is known that latter on the Federal Reserve changed participations regularly to maintain district gold balances.

13. This point was noted by Fels (1950), and Hartland (1950).

14. Trade weighted terms of trade by census region were computed by Waite (1942). I calculated the terms of trade for the Eastern Financial districts by weighting his indexes for New England and the Middle Atlantic states by their shares in regional personal income. I haven't found the explanation for the sharp drop in the terms of trade in 1932.

15. The per capita income figures by state are widely available. I created federal district estimates simply by adding the personal incomes of each state in the district. Where only a part of a state was included in a district I simply made a guess as to the fraction of the state's economic activity that occurred in a particular district. Overall the estimates do not appear sensitive to these guesses.

16. A chart of reserve growth is similar.

17. More precisely, the first 10 months of the contraction. The NBER business cycle peak occurs in August 1929.

18. I examined the state level data that underlies Bodenhorn's regional estimates, but failed to turn up obvious increases due to banking panics or liquidity shortages. I am grateful to Professor Bodenhorn for sharing his state-level estimate.

19. The nominal rates are from Smiley $(1981,897)$. The wheat rate of interest was computed by subtracting the percentage change in the price of a bushel of wheat (U.S. Bureau of the Census 1975, 511, series K508) between 1928 and 1929 from the 1929 nominal loan rate, and the percentage change between 1929 and 1930 from the 1930 nominal loan rate.

20. Similar restrictions were adopted in Argentina in December 2001 during its financial crisis.

21. The holiday was declared in order to give the state's largest bank time to apply for a Reconstruction Finance Corporation Loan, a consideration that was also behind some of the other holidays. The pressure on the bank determined the date; the occasion was found afterwards, the anniversary of the severance of diplomatic relations with Germany prior to World War I! (Chandler 1970, 120).

22. Ballantine, the Under Secretary of the Treasury, took part in the negotiations with Henry Ford. 
23. This section is based on Friedman and Schwartz (1963, 370-4).

24. The failure to distinguish between nominal and real rates was stressed by Brunner and Meltzer (1968).

25. The success of the Canadian banking system in avoiding a U.S. style collapse does not mean that Canada avoided the Great Contraction. Industrial production in Canada followed the same downhill path as in the United States. 